\title{
Aspects of accumulated heat patterns (growing degree-days) and pasture growth in Southland
}

\author{
G.K. HUTCHINSON ${ }^{1}$, K. RICHARDS ${ }^{2}$ and W.H. RISK ${ }^{3}$ \\ ${ }^{1}$ Topoclimate South Project, 59 Main Road, Mataura \\ ${ }^{2}$ Geography Dept., Otago University, P.O. Box 56, Dunedin \\ ${ }^{3}$ Topoclimate South Project, 59 Main Road, Mataura \\ garyh@topoclimate-south.co.nz
}

\begin{abstract}
In cooler regions of New Zealand, temperature and patterns of accumulated heat are important limits on pasture growth, especially over the period from late autumn to spring, and data on these factors are crucial for best land-use management in the southern farming community. The Topoclimate South Project is mapping soil and climate characteristics over 805000 ha of Southland/South Otago using a network of 900 automated dataloggers. Temperature data for individual sites, and from local climate stations are being used to generate 30-year daily temperature and, thereafter, growing degree-day (GDD) records. Literature reviews show that several authors report considerable growth of temperate pasture species at about $5^{\circ} \mathrm{C}$, so a base temperature of $4^{\circ} \mathrm{C}$ is used as a threshold for pasture growth and, thus, in GDD computations. Strong relationships are evident when pasture growth rates and GDDs are compared. For data recorded at Winton, Southland in the period 1950-1961, GDD patterns strongly reflect patterns of both clover and grass growth, accounting for $88 \%$ of the variability in mean patterns of clover growth and $75 \%$ of the variability in total pasture production. In practice, rainfall seasonality, nutrients, solar radiation, pasture management, plant pests and plant ecotype will also affect growth rates. To ensure that information gathered is also communicated, Topoclimate South is issuing soil and GDD maps to participating farmers. They have also established a service to provide detailed information and interpretation for end users, be they farmers, scientists, teachers, consultants or other service providers to the agricultural community.
\end{abstract}

Keywords: growing degree-day, pasture growth, temperature threshold, topoclimate

\section{Introduction}

In general, pasture growth is limited by solar radiation, temperature, water stress, nutrient availability and grazing management. Most water, nutrient and management related limitations can be ameliorated although this is not always economically viable - but solar radiation and outdoor temperatures cannot (Cooper \& Breese 1971). Thus, in cooler regions of New Zealand, temperature and patterns of accumulated heat are important limits on pasture growth, especially during the period from late autumn to spring.

In Southland/South Otago, the farming community has identified a need for detailed data on climate and soil factors. To provide these data, the Topoclimate South Project is currently mapping soil and climate characteristics over 805000 ha using a network of 900 automated data loggers. Temperature data for individual sites, and from local climate stations, are being used to generate 30 -year daily temperature records and, thereafter, heat accumulation records. Maps of soil and heat accumulation will then be created using a geographic information system (digital mapping programme) (Figure 1).

In the project, heat accumulation is expressed as growing degree-days (GDD; in units ${ }^{\circ} \mathrm{C}$ ). That is, the sum of daily mean temperatures above a chosen threshold for a stated period, e.g., for 1 year:

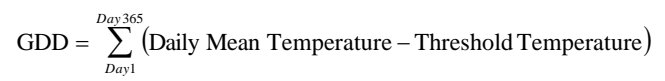

A fundamental question is, therefore, what is the appropriate threshold? Or - to tighten the focus - at what temperature does growth begin in spring for temperate pastures in Southland?

As a first approximation, the boundary conditions chosen for published growth experiments suggest temperatures at which temperate pasture species such as perennial ryegrass (Lolium perenne), cocksfoot (Dactylis glomerata) and white clover (Trifolium repens) are perceived to grow. In experiments in the United Kingdom and New Zealand (Table 1), the "cool limit" for such experiments can be as low as $4.4^{\circ} \mathrm{C}$ for temperate grasses and $9^{\circ} \mathrm{C}$ for white clover. Growth rates in these experiments are typically least at these limits but such data do not establish whether growth would have occurred at lower temperatures.

Alternatively, one can consider published thresholds for growth of pasture species. The commonly cited 
Figure 1 Long Term Annual Heat Pattern for the Heriot District, West Otago - Growing-Degree Days of Accumulated heat above $4^{\circ} \mathrm{C}$ Base Temperature.

Reproduced from: Hutchinson, G.K.; Risk, W.H.; Richards, K. 2000: Long Term Annual Heat Pattern for the Heriot District. Scale 1:50,000. Topoclimate South Climate Map 3b. Topoclimate South, Mataura, New Zealand.

minimum temperature thresholds for growth are $5^{\circ} \mathrm{C}$ for temperate grasses and $9-10^{\circ} \mathrm{C}$ for white clover (Table 2). However, several authors report considerable growth of temperate grasses at $5^{\circ} \mathrm{C}$ or less. For white clover, evidence shows that white clover can grow actively at $5^{\circ} \mathrm{C}$, and leaf production - i.e., prior to actual leaf elongation - can occur at even $2-3^{\circ} \mathrm{C}$. Actual growth rates depend strongly on ecotype or place-of-origin, e.g., grass varieties with Mediterranean origins tend to grow actively at $<5^{\circ} \mathrm{C}$, whereas plants with high latitude or continental origins grow very slowly or not at all at $5^{\circ} \mathrm{C}$. The pattern is usually 
Table 1 Cool limits in experimental studies of growth rates of a) common temperate grasses and b) white clover. (K. Richards pers. comm.)

\begin{tabular}{cccc}
\hline---- & Indicative temperature $\left({ }^{\circ} \mathrm{C}\right)$ & $--\cdots------$ \\
$\begin{array}{c}\text { Daily mean } \\
\text { value }\end{array}$ & $\begin{array}{c}\text { Night/day } \\
\text { regime }\end{array}$ & $\begin{array}{c}\text { Constant } \\
\text { value }\end{array}$ & $\begin{array}{c}\text { Ambient } \\
\text { value }\end{array}$ \\
\hline
\end{tabular}

a) Common temperate grasses

\section{2}

7.2

$\begin{array}{ll} & \text { Mitchell (1956)* } \\ & \text { Mitchell \& Lucanus (1962) } \\ 5 & \text { Barthram \& Grant (1994) } \\ 5 & \text { Cooper \& Breese }(1971)^{*} \\ & \text { Mitchell \& Lucanus (1960) }\end{array}$

$4.4 \quad 1.7 / 7.2$

b) White clover

\begin{tabular}{|c|c|c|c|c|}
\hline & & \multicolumn{2}{|l|}{10} & Eagles \& Othman $(1986)^{*}$ \\
\hline 9.25 & $6 / 12.5$ & & & Williams \& Hoglund (1978) \\
\hline \multirow[t]{3}{*}{9} & $6 / 12$ & 6 & & Junttila et al. $(1990)^{*}$ \\
\hline & & 7.2 & & Mitchell (1956)* \\
\hline & & 7.2 & & Mitchell \& Lucanus (1962) \\
\hline \multirow[t]{2}{*}{6} & $4 / 8$ & & & Woledge \& Suarez (1983)* \\
\hline & & & 5 & Barthram \& Grant (1994) \\
\hline 4.4 & $1.7 / 7.2$ & & & Mitchell \& Lucanus (1960) \\
\hline
\end{tabular}

* Slowest growth rates observed at the cool limit of the study

of pasture growth are rare in New Zealand: short-term experiments on individual species (e.g., Mitchell 1956), and broad-scale environmental studies (e.g., Campbell et al. 1999b) are more typical approaches. The historical data presented here are thus rare, and consist of mean fortnightly pasture-yield and annual pasture-yield data gathered at Winton, Southland over an 11-year period from 1950 to 1961 (Radcliffe 1974). These data can be compared to GDD values computed for the nearby Otautau climate station for equivalent periods, using daily temperatures sourced from NIWA's climate database. Rainfall data (NIWA, unpublished) for Winton were also used.

\section{Methods}

explained as follows: in Mediterranean environments summer drought is limiting so plants tend to grow actively at low temperatures, whereas in northern/ continental climates winter cold is limiting and ecotypes of these origins (wherever they are planted) tend to be inactive at cool temperatures (Cooper 1964).

Taken together, a threshold of $4{ }^{\circ} \mathrm{C}$ seems justifiable for temperate pasture. This temperature has been adopted by Topoclimate South as a suitable threshold for pasture growth in Southland and, thus, has been used in initial computations of GDD and subsequent maps. In practice, species composition, rainfall seasonality, soil nutrients, solar radiation, grazing management, pests, and plant ecotype will affect actual growth rates for any particular species, date or location.

This paper presents selected aspects of ongoing topoclimatological research. Long-term, detailed studies
Daily $\mathrm{GDD}_{4}$ and $\mathrm{GDD}_{10}$ values were computed using base temperatures of 4 and $10^{\circ} \mathrm{C}$, respectively. Daily mean temperatures were found as the average of daily minimum $\left(\mathrm{T}_{\mathrm{Min}}\right)$ and maximum $\left(\mathrm{T}_{\mathrm{Max}}\right)$ temperatures at Otautau (all with units ${ }^{\circ} \mathrm{C}$ ):

$$
\mathrm{GDD}_{4}=\frac{\mathrm{T}_{\mathrm{Max}}+\mathrm{T}_{\text {Min }}}{2}-4 \text { and } \mathrm{GDD}_{10}=\frac{\mathrm{T}_{\mathrm{Max}}+\mathrm{T}_{\text {Min }}}{2}-10
$$

After the method of Radcliffe (1974), daily GDD values were summed to give annual data for the periods 1 June-31 May, 1950/51 to 1960/61. Long-term (11year) mean fortnightly values were also computed. Pasture growth and GDD data for equivalent periods were analysed primarily by step-wise linear regression analysis.

Table 2 Possible cool thresholds for growth of a) temperate grasses and b) white clover. Subscripts a and $s$ indicate air and soil temperatures, respectively. (K. Richards pers. comm.)

Suggested threshold $\left({ }^{\circ} \mathrm{C}\right)$

a) Common temperate grasses

5- $6^{\circ} \mathrm{C}$

$5^{\circ} \mathrm{C} \mathrm{T}_{\mathrm{s}}$

$5^{\circ} \mathrm{C} \mathrm{T}_{\mathrm{a}}$

5 or $\angle 5^{\circ} \mathrm{C}$

b) White clover

10 or $<10^{\circ} \mathrm{C}$

9 or $<9^{\circ} \mathrm{C} \mathrm{T}_{\mathrm{s}}$

$7^{\circ} \mathrm{C} \mathrm{T}$

$<5^{\circ} \mathrm{C} \mathrm{T}_{\mathrm{s}}$ or $\mathrm{T}_{\mathrm{a}}$ $2-3^{\circ} \mathrm{C} \mathrm{T}_{\mathrm{a}}$
Munro \& Hughes (1966) cited in Ollerenshaw \& Baker (1981)

Peacock (1976)

Cooper \& Breese (1971)

Cooper (1964)***

Gibson \& Hollowell $(1966)^{* * *}$ cited in Eagles \& Othman (1986); Olusuyi \& Raguse (1968) cited in Eagles \& Othman (1986); Kemp \& Liu (1992)

Munro \& Hughes (1966) cited in Ollerenshaw \& Baker (1981); Munro (1970) cited in Eagles \& Othman (1986)

Leaf expansion: Haycock (1981) cited in Campbell et al. (1999a)

Ollerenshaw \& Baker $(1981)^{\star *}$; Campbell et al. $(1999 a)^{*}$

Leaf production: Haycock (1981) cited in Campbell et al. (1999a)

* Growth acknowledged as ecotype dependent; ** Growth seen at this temperature 


\section{Results}

Figure 1 presents long-term (1950-61) mean fortnightly pasture-yield data for Winton, and mean fortnightly GDD values for the same period. The mean GDD patterns strongly reflected mean patterns of both clover and pasture growth. The match was best for white clover and $\mathrm{GDD}_{10}$ data. Analyses show that variation in $\mathrm{GDD}_{10}$ accounted for $88 \%$ of the variability in mean patterns of clover yield, and variation in $\mathrm{GDD}_{4}$ accounted for $75 \%$ of the variability in mean total pasture production (i.e., $\mathrm{r}^{2}$ values for goodness-of-fit were 0.88 and 0.75 , respectively). The match was weaker for grasses alone: $59 \%$ of yield variation was explained by GDD 4 variation $\left(r^{2}=0.59\right)$.

It must be noted that these correlations were only seen in the long-term mean data. Similar relationships are not evident - and were not expected - for individual years (resulting $\mathrm{r}^{2}$ values were $<0.07$ or $7 \%$ ). In other words, at the annual scale, high total pasture yields did not always correlate with high GDD values and vise versa (Table 3). For example, 1956/57 had aboveaverage pasture growth and $\mathrm{GDD}_{4}$ values and 1952/53 had below-average values in both factors. However, in 1955/56 pasture yields were low despite higher than average GDD 4 values, and in 1959/60 the reverse was seen. This pattern is attributed to unknown variation in environmental factors besides GDDs, probably moisture availability, but inclusion of annual (Table 3) or seasonal (not shown) rain data did little to improve the fit.

\section{Discussion}

These results demonstrated that long-term mean pasture growth and patterns of heat accumulation (GDDs) are strongly correlated. Assuming light, water and nutrients are not limiting, a threshold for growth of $4^{\circ} \mathrm{C}$ (mean daily air temperature) seems justified for temperate pasture. However, some species (e.g., white clover) and populations may grow slowly at this temperature.

Actual growth rates will reflect other environmental factors that have a significant impact on growth rates, i.e., soil nutrients, grazing management, pest levels, and climatic variables such as rainfall and solar radiation. At Winton, long-term mean rainfall is evenly distributed throughout the year, although less so than assumed by Radcliffe (1974) (Table 3). Periods of excess and deficit occur at annual and seasonal scales and the precise timing of rain relative to plant life cycles may prove to be a crucial factor. Rainfall effects cannot be investigated in isolation from those of, say, grazing management or nutrient levels. Unfortunately, little additional data are available for the Winton study,
Figure 2 Long-term mean fortnightly pasture yield and growing degree-days for Winton, Southland. Data are averaged for the period 1950 to $1961 . \mathrm{GDD}_{10}$ and $\mathrm{GDD}_{4}$ indicate base temperatures of 10 and $4^{\circ} \mathrm{C}$, respectively (Source: derived from Radcliffe (1974) and NIWA (unpublished data)).

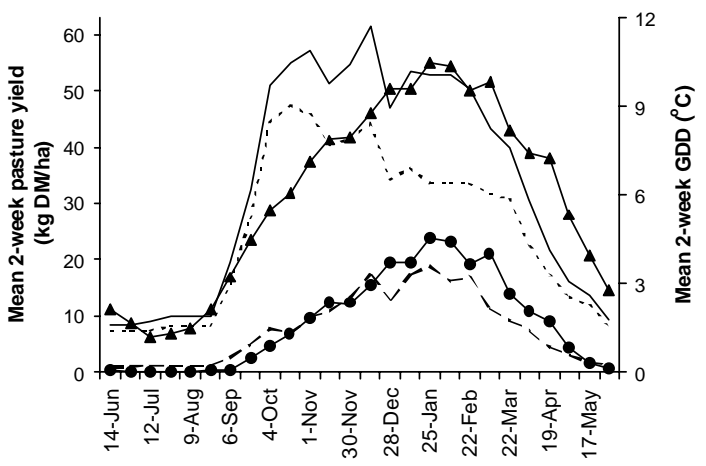

For 2 weeks ending on date shown

\begin{tabular}{ll|}
$\longrightarrow$ Total growth & $\cdots \cdots$ \\
$\longrightarrow$ GDD10 & $\longrightarrow$ Grass growth --- Clover growth \\
\end{tabular}

Table 3 Annual pasture yield, growing degree-days $\left(\mathrm{GDD}_{4}\right)$ and rainfall for Winton, Southland, for the 11 years (1 June31 May) 1950/51 to 1960/61. (Source: derived from Radcliffe (1974) and NIWA (unpublished data)).

\begin{tabular}{lccc}
\hline Year & $\begin{array}{c}\text { Annual pasture } \\
\text { growth } \\
(\mathrm{kg} \mathrm{DM} / \mathrm{ha})\end{array}$ & $\begin{array}{c}\text { Annual } \\
\mathrm{GDD}_{4} \\
\left({ }^{\circ} \mathrm{C}\right)\end{array}$ & $\begin{array}{c}\text { Annual } \\
\text { rainfall } \\
(\mathrm{mm})\end{array}$ \\
\hline $1950 / 51$ & 9080 & 2129 & 763 \\
$1951 / 52$ & 11150 & 2016 & 964 \\
$1952 / 53$ & 8870 & 2072 & 884 \\
$1953 / 54$ & 14730 & 2153 & 768 \\
$1954 / 55$ & 12850 & 2351 & 847 \\
$1955 / 56$ & 9850 & 2353 & 794 \\
$1956 / 57$ & 14590 & 2327 & 1040 \\
$1957 / 58$ & 11940 & 2034 & 1183 \\
$1958 / 59$ & 11710 & 2265 & 866 \\
$1959 / 60$ & 16000 & 2180 & 806 \\
$1960 / 61$ & 11380 & 2169 & 904 \\
\hline Mean & 12014 & 2186 & 893 \\
\hline
\end{tabular}

so precise relationships are beyond the scope of this paper. Further research, for this and other case studies, is required to determine the exact nature of such relationships.

The practical implications of temperature and GDD information to the Southland community are immense. For example, climate information can help farmers choose new crops, assist flower growers to assess frost risk (or in contrast, find sites with suitable chillingunits), and aid real estate agents in the pricing of rural land. Consequently, the Topoclimate South Charitable 
Trust has established a service to provide data and interpretation for Southland farmers and is issuing free soil and GDD maps to those who participated within the survey area. Other productivity and diversification information is also being offered in conjunction with AgriQuality NZ Ltd as partners.

\section{REFERENCES}

Barthram, G.T.; Grant, S.A. 1994. Seasonal variation in growth characteristics of Lolium perenne and Trifolium repens in swards under different managements. Grass and Forage Science 49: 487-495. Abstract: www.webofscience.com.

Campbell, B.D.; Caradus, J.R.; Hunt, C.L. 1999a. Temperature responses and nuclear DNA amounts of seven white clover populations which differ in early spring growth rates. New Zealand Journal of Agricultural Science 42: 9-17.

Campbell, B.D.; Mitchell, N.D.; Field, T.R.O. 1999b. Climate profiles of temperate C-3 and subtropical C-4 species in New Zealand pastures. New Zealand Journal of Agricultural Research 42: 223-233.

Cooper, J.P. 1964. Climatic variation in forage grasses. Journal of Applied Ecology 1: 45-62.

Cooper, J.P.; Breese, E.L. 1971. Plant breeding: forage grasses and legumes. pp. 295-318. In: Potential crop production. Eds. Wareing, P.F.; Cooper, J.P. Heinemann Educational Books, London.

Eagles, C.F.; Othman, O.B. 1986. Effect of temperature, irradiance and photoperiod on morphological characters of seedlings of contrasting white clover populations. Annals of Applied Biology 108: 629638.

Junttila, O.; Svenning, M.M.; Solheim, B. 1990. Effects of temperature and photoperiod on vegetative growth of white clover (Trifolium repens) ecotypes. Physiologia Plantarum 79: 427-434.
Kemp, D.R.; Liu, G.B. 1992. Winter temperatures and reproductive development affect the productivity and growth components of white clover and phalaris growing in a mixed pasture. Australian Journal of Agricultural Research 43: 673-683. Abstract: www.webofscience.com.

Mitchell, K.J. 1956. Growth of pasture species under controlled environment. I. Growth at various levels of constant temperature. New Zealand Journal of Science and Technology 38A: 203-216.

Mitchell, K.J.; Lucanus, R. 1960. Growth of pasture species in controlled environment. II. Growth at low temperatures. New Zealand Journal of Agricultural Research 3: 647-655.

Mitchell, K.J.; Lucanus, R. 1962. Growth of pasture species under controlled environment. III. Growth at various levels of constant temperature with 8 and 16 hours of uniform light per day. New Zealand Journal of Agricultural Research 5: 135-144.

Ollerenshaw, J.H.; Baker, R.H. 1981. Low temperature growth in a controlled environment of Trifolium repens plants from northern latitudes. Journal of Applied Ecology 18: 229-239.

Peacock, J.M. 1976. Temperature and leaf growth in Lolium perenne. II. The site of temperature perception. Journal of Applied Ecology 12: 115-123.

Radcliffe, J.E. 1974. Seasonal distribution of pasture production in New Zealand. New Zealand Journal of Experimental Agriculture 2: 341-348.

Woledge, J.; Suarez, A.C. 1983. The growth and photosynthesis of seedling plants of white clover at low temperature. Annals of Botany 52: 239-245.

Williams, W.M.; Hoglund, J.H. 1978. Temperature responses of New Zealand, Spanish, and New Zealand x Spanish white clover populations. New Zealand Journal of Agricultural Research 21: 491497. 
